\title{
Profiting from Poverty? A Case Study of UK based Microfinance Institutions
}

\author{
Nitin Navin*
}

\begin{abstract}
The success of the microfinance movement is beyond doubt. However, as the scope of the sector increased and commercialised, some problems of it became evident. Issue of profitability and sustainability of Microfinance institutions (MFIs) and, use of external capital by them are the two most debatable issues of the microfinance sector. The current study investigates these issues by targeting MFIs and consultants of microfinance sector located in UK. These MFIs and consultants have operations in different poor and developing countries. The study found that believing that MFIs can alone eliminate poverty is a fallacy. Any such belief by the policymakers will make further delay in eradicating poverty. The study also found that financial sustainability of microfinance seems to remain unachievable for most of the MFIs and, that there are fair chances of having trade-off between financial performance and social performance for those MFIs. On this line of thought, the study concludes by arguing that microfinance cannot be treated only as a substitute of the traditional financial services.
\end{abstract}

Key words: Microfinance, mission drift, poverty eradication, sustainability.

\subsection{Introduction}

It is important for any economically growing country that its growth strategy should be inclusive. Any such growth should touch and improve the life of every citizen. Financial services play a very important role in ensuring inclusive growth. They might not lift the poor out of poverty but, they improve the quality of life by opening new avenues of future growth. Limited access to financial services is a major bottleneck for people in developing countries wanting to improve their livelihoods (Kono \& Takahashi, 2010). All over the world, the financially weaker section of the society is either unable, reluctant or denied financial services of formal financial institutions.

*Assistant Professor, Satyawati College, University of Delhi. 
2 | MUDRA: Journal of Finance and Accounting, Volume 2, Issue 2

Such exclusions range from partial exclusion in developed countries to full exclusion in lesser developed countries (Brau \& Woller, 2004) and, are generally on the grounds of associated high cost and risk. Micro-finance is 'banking for the poor' (Kandelwala, 2007). It is a broad category of services, which involve financial as well as non-financial services, including the most important service of microcredit, especially designed for the people whose incomes are not only just low but also volatile. This way it promises to improve the allocation of capital and to expand opportunities for the larger section of the society (World Bank 2008).

Initially, microloans were meant to provide a kinder, cheaper alternative. Mhd. Yunus and his Grameen Bank in Bangladesh put forward a new type of entrepreneurship that concerned with "social business" whose bottom line would be "doing good' (Yunus, 2006). In the line with the market failure theory of microfinance ${ }^{1}$, Yunus (2008) finds MFIs as substitutes of commercial banking sector which try to solve the limitations of the traditional banking sector by using different lending methodologies. Moreover, microfinance can combine the good features of both formal as well as informal credit. Such services increases freedom since it gives the poor a new way to navigate tricky financial currents (Sen, 1999) and, also protect the poor from the clutches of the usurious money lenders and make it possible for governments to make payments such as social security transfers (Subbarao, 2009).

Later, it was proposed that it is possible to eradicate poverty through profit and argued that markets, rather than market failure, is the key theme of microfinance ${ }^{2}$. This new model emphasizes on profit and introduces strict norms of financial sustainability to ensure accountability. It is argued that MFIs should commercialize and maximize their profitability, in order to extend their operations in new areas.

By the late 1980s, microcredit and microenterprise development had become the international development community's anti-poverty intervention of choice. The UN celebrated the year 2005 as the 'International Year of Microcredit'. In 2006, Nobel Prize, awarded to Muhammad Yunus and Grameen, brought the microfinance into limelight. Government of different countries initiated programmes directed to providing small loan to the poor. According to the Microcredit Summit Campaign (2012), the number of very poor families with a microloan has grown more than 18 fold from 7.6 million in 1997 to 137.5 million. While most of the MFIs started as NGOs, they have increasingly transformed in commercial institutions. This transformation has been accompanied by changes in the structure of ownership, control and management of MFIs and, the nature of their stakeholder commitment (Nair, 2010). Many big formal financial organisations came into the picture making the microfinance sector more commercialised. In recent 
years, investors have flocked to microfinance to add depth in their portfolio besides for social and financial returns.

It is widely acknowledged that micro-finance institutions can play an important role in improving the quality of life of the poor by designing and providing financial assistance keeping in view its need ${ }^{3}$. However, there is no consensus on the extent of the impact of microfinance on the poor. It ranges from substantial positive (Khandker, 2005; Bellman \& Chang, 2010) to insignificant or no impact (George, 2005; Coleman, 2006; Banerjee et al., 2013). Moreover, a section of authors though, are in agreement with the fact micro finance is an important tool against poverty but, rejects to endorse it as the only effective tool in doing so ${ }^{4}$. Furthermore, concerns are raised on the potential damage, micro finance could make if things go wrong ${ }^{5}$. The on-going commercialisation of MFIs and advent of giant players in the microfinance sector have accelerated the use external sources of finance in the sector. It is quite possible that in order to remain attractive for investors, such MFIs become more inclined (or compelled) to maximize their profits and, go for blind expansion of their lending services with exploitative loan recovery mechanism and high lending rates. It is also fund that MFIs are, to some extent, neglecting the poorest borrowers in their urge to expand and reduce unit costs. Furthermore, the relationship between the MFI and the client is reduced to one that is very similar to retailing (Sinha, 2011). The recent turmoil in microfinance sector in Andhra Pradesh, India and, it's wide implications has drawn the attention of the policymakers, researchers and service providers on such issues.

The current study attempts to investigate some the above mentioned issues by targeting service providers and consultants of microfinance sector located in UK and having operations in different countries of Africa and India. The main aim is to get and analyse their positions on abovementioned issues.

\subsection{Research Methodology}

The current study attempts to highlight the views and ideas of the services providers of the microfinance services with more focus on 'how' rather than 'how many'. Therefore, interview method is applied to collect more detailed responses and individual experiences. Interviews are the preferred method in human-science and involve description, interpretation, and a self-reflective and critical analysis (Van Manen, 1990). It provides a deeper picture of the research question as the materials generated by it are analysed using a textual approach, relying on words and meanings, rather statistics. 
4 | MUDRA: Journal of Finance and Accounting, Volume 2, Issue 2

One of the main problems with interview method is that the researcher has to set things up by asking questions to respondents. By contrast, the beauty of naturally occurring data is that they may show us things we could never imagine. But, data cannot be intrinsically unsatisfactory; it all depends on what we want to do with (Silverman, 2010). To further ensure flexibility in the way issues are addressed by the interviewee, semi-structured interview method is used. Follow-up questions had been framed to get clarification, precision, verification and contradiction for any claim of the interviewee. Another important issue is that any use of interview material without theoretical understanding supporting critical judgement, risks naivety and leave interpretations poorly grounded (Alvesson \& Ashcraft, 2012). Therefore, a detailed study of the related available documents was done and emerging trends were identified from the text materials. All the interview conversations were properly recorded and transcribed. Nvivo10 software was also used for making categories and sub-categories. Themes were built to connect the empirical findings with a broader literature review in order to draw conclusions.

While selecting participants and deciding on how to utilize their accounts, two guiding principles were kept in mind. First, attempt was made to interview persons having different responsibilities in their respective organisation to get a complete picture of the affairs of the topic. Second, considerable attention was paid to those participants who can provide authentic and insightful information. Therefore, top officials of MFIs and donor organisation were contacted. These officials have different job profile in their respective organisation. Furthermore, consultants having wide experience of microfinance sector were also contacted. The probable risk of using such well-selected interviews is that it give researcher temptation to overemphasize, or represent as 'universal', the voices of those with whom it share a common prejudice. This is kept in mind while concluding the findings of the study.

The study contacted MFIs, consultants, and donor groups located in UK. There are approximately 15 MFIs and International NGOs in UK providing microfinance services to the poor, either directly or through local partners in different countries of Afrian and Asian region. As these institutions have operations in different developing countries of the world, the study successfully got the diverse experience of microfinance sector from different countries. The contacted MFIs include profit making, non-profit making, charitable MFIs, MFI providing peer-to-peer lend platform, and MFIs using external capital. A formal request letter with a brief overview of the planned study was sent to more than 30 respondents.

While contacting Citi and Barclays, the study found that the customer care of Citi and Barclays had no idea about the microfinance business of their respective 
organisations. This is quite shocking as both the organisations sensationally promoting their microfinance services. The Department for International Development (DIFD) took 15 days to tell the name and email id of a particular official who can provide the desired information about its microfinance-related aid. Request letter and later, reminder letter, were sent to that official but, all remained unattended. The London office of Gates Foundation was also contacted as they provide financial help to MFIs. They advised to contact their US office. However, the study failed to get response from there.

The study got initial positive reply from 17 respondents. One respondent felt that it did not have much information on the topic. Another respondent never gave time for interview. Two for-profit MFIs, both big players, sent web links of the particular pages containing information about their business model and achievements but, declined to give time for the interview. However, it was decided to exclude those pieces of information in the absence getting chance to have interaction in person.

\subsection{Results and Analysis}

With the aforesaid objectives, 13 interviews were conducted. The findings are analysed and results are presented in the next section.

\subsection{Basic idea of microfinance}

In order to get a better idea of the functioning of the different MFIs and consultants working in the microfinance sector, interviewed in this study, it was asked to them to define the term 'microfinance' as per their own basic understanding. All the respondents related microfinance with poverty and financial exclusion but, in different ways. They had a view that poverty results in financial exclusion, and financial exclusion reinforces poverty still further. One of the participants highlighted that the financial exclusion could be because of many other reasons also.

The study found the respondents are quite aware of the fact that microfinance is an effective tool for the betterment of the marginalised section of the society and the main objective of it goes beyond delivering financial services. Some of the respondents related microfinance services with financial freedom and self-respect of the poor. The Programme Manager of one leading charitable MFI states,

"....Say if you build a school or hospital in community, it is your decision but, if you are providing financial services you are powering the local community to do what they want with their own money."

This way MFI provides the much-needed capital with some basic training and leaves the clients to use the money as per their preference of particular business. And, 
6 | MUDRA: Journal of Finance and Accounting, Volume 2, Issue 2

when the business gets initial success, other financial services such as savings and micro insurance bring sustainability in the clients' life. With consistent growth in income, qualitative improvements happen in the life of their families. Here, some of the respondents emphasized more on providing financial services, namely microcredit and savings, while others gave equal importance to provide training for basic business skills and financial literacy. Non-profit and charitable MFIs had a view that social awareness programmes should be supplemented with microfinance services for qualitative improvements in the life of the poor clients.

\subsection{Tool against poverty}

On asking whether microfinance can eliminate poverty alone, all the respondents replied in negative. Irrespective of the different set-up of their respective organisations, most of the respondents have a clear understanding about the strengths and limitations of microfinance in helping the poor. The programme manager of one non-profit MFI remarks,

“..it (microfinance) does not always reduce poverty, what it does, hopefully, is built up resilience and reduce vulnerability."

All the respondents shared a view that financial services can increase freedom, but they do not automatically do so. They also cautioned that while disbursing credit, its dual nature (a source of possibilities and a liability, as well) should be kept in mind, especially when the borrower is very poor. One senior micro finance consultant stated that poor people generally did not have much to save and avoid taking loans. In place of these services, they look for job opportunities at the initial level. Some of the respondents mentioned that MFIs never reached to extremely poor people and, it cannot be an effective tool against poverty in those areas where potential clients are extremely poor. There is a need of specialised programmes in such areas ${ }^{6}$. This finding is consistent with the findings of Cheston \& Leeds (1999), Tazul Islam (2007) and, Shirazi \& Khan (2009). It hints that an important development objective of microfinance, outreach to the poor, might be ignored in the quest for low costs and high growth (both are crucial to remain attractive to potential investors) as rewards of being the first mover in microfinance are limited (or mostly reverse).

All respondents shared a view that micro finance is, undoubtedly, an effective mean for income generation, but it is important to understand how microfinance can contribute more to development. They stated that microfinance can be effective only when it is accompanied by traditional aids, government support, and healthy macro environment. The programme director of leading non-profit making MFI states, "It (Microfinance) is more like a catalyst. It speeds up the development process" 
So, as a catalyst, microfinance speeds up the process of development by enhancing the abilities of poor to reap the benefits and opportunities, already exist in a growing economy. But financial services and training, alone, cannot create such conducive environment for growth. Here, the role of government and private sector is very important. Two respondents stated that their respective organisations provide micro loans to farmers but, those farmers also need good-quality seeds, fertilizers, information, a fair market price of their produce and, connectivity to the nearest market. These essential facilities can only be provided by the local government and the market. In the absence of any of these facilities, chances of financial distress for the poor farmer will remain high. The findings re-strengthen the doubts raised by Guress (2008) and Karnani (2009) on the ability of microfinance to alleviate the poverty alone.

\subsection{Significance of sustainability and profitability in microfinance}

Every MFI has very clear set of social objectives at the time of starting the operations. Often, the basic objective of MFIs is to provide financial and non-financial services in such a way that helps the poor to move themselves out of poverty. It has to offer an array of financial and non-financial services to attain those objectives. Moreover, non-financial services, like financial education and training for developing basic business skills in the poor clients start well before offering financial services to them. What makes an MFI different from other financial institutions is the very fact that for the former, the end objective goes beyond delivering services in a business-like way. Therefore, all these training and awareness programmes are free for the clients though, incurs cost to MFIs.

An important financial service, accepting savings from clients, is not always possible for the MFIs (mostly due to regulation). Moreover, charging very high rate of interest on loans (which is already higher than that of commercial banks) to attain selfsustainable, will again defeat the very purpose of MFIs' existence and, also increases the loan default rate, making the situation worse. This makes MFIs extra vigilant on getting the repayment of the loan on time. And, many times such pressure results in violence against client who fails to pay back on time.

With the emergence of MFIs, following the profit maximising poverty alleviation strategy, a new debate started that whether such organisations can attain the dual objectives without harming the poor clients or not. Figure 1 shows the challenge for an MFI to maintain a balance between two sets of objectives which act in opposite direction. 
8 MUDRA: Journal of Finance and Accounting, Volume 2, Issue 2

Figure 1: Challenge for MFIs in balancing Social and Financial Objectives

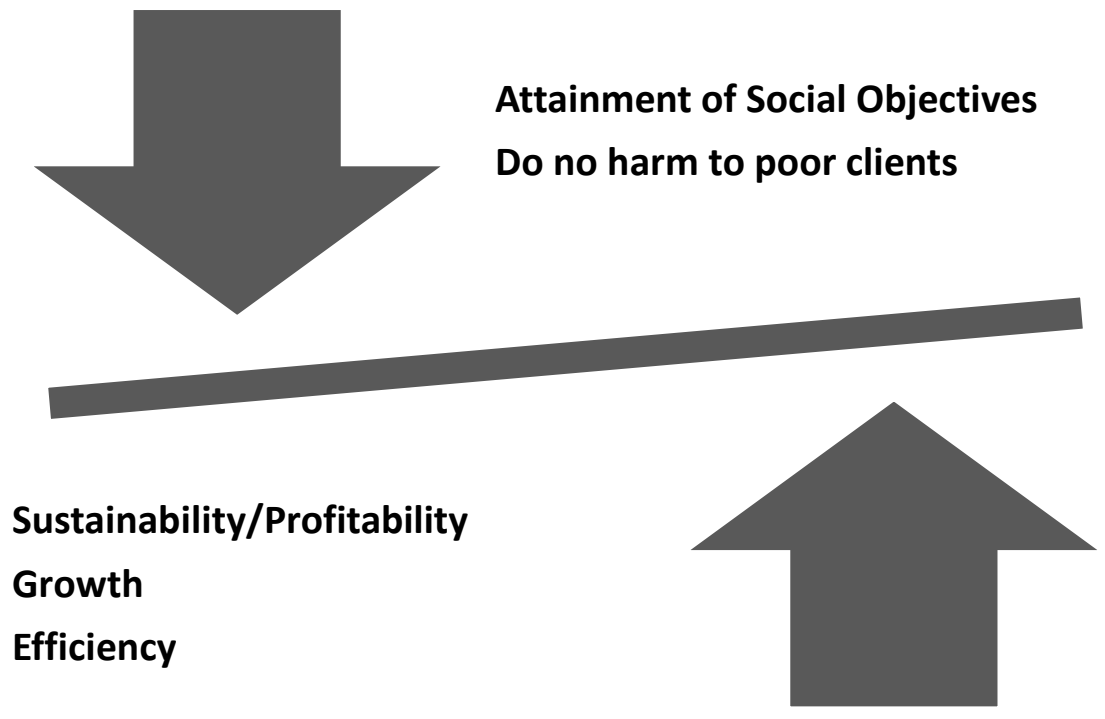

The current study attempts to find how MFIs deal with such situation. A series of questions were asked to the respondents in this regard. All the respondents mentioned sustainability of the MFI as a necessary condition to work and to further enhance the outreach of the organisation. It is worth to mention here that all the not-for-profit MFIs clearly mentioned their struggle to raise enough funds in the wake of the recent financial crisis. Some of the respondents had a view that slow growth of micro finance in the past was mainly due to over dependence of the sector on donations and subsidies. According to them, MFIs have to make their operations self- sustainable to reach more and more poor and to provide more financial and non-financial services.

Some respondents also related the issue of sustainability with financial discipline of the organisation. Most of them do not find the issue of sustainability opposite to the social objectives of micro finance in the long run. It is also found that microloans of MFIs cannot be treated only as acts of charity. It is also an attempt to fill a gap in the market. On the issue of using external finance, views of the respondents differ.

\subsection{Fear of mission drift}

Treating the poor as lucrative market with the assumption of 'win-win' situation; earning handsome return by providing financial services to them, has made the microfinance sector highly commercialised. Big financial institutions like, Citigroup, 
Barclays, Morgan Stanley, etc. have entered in the fray either, by collaborating with MFIs or by creating funds for investors to gain exposure to the growing field. This has increased the possibility of 'mission drift' for MFIs. Muhammad Yunus, the Nobel laureate pioneer of microcredit, claimed,

"When you are making profits you are moving into the mentality of the loan shark." (Financial Times, 2008, p. 1)

On the possibility of any such mission drift for MFIs with the growing commercialisation of the sector, most of the respondents agreed that there is such possibility. Not-for-profit MFIs seemed more worried and shared same reason behind their fear. Launching of micro finance services by big banks and other giant financial institutions were also seen as threat. The CEO of one leading non-profit MFI blamed the blind social investment which is being poured in microfinance. According to him such investment has no regard for the social impact at the ground level. Some respondents did not deny chances of such mission drift, but they disapproved that commercialisation of MFI is the main reason behind any such drift. They have a view that MFIs can develop many ways to remain socially driven without losing their profitability.

\subsection{Issue of Profit vs. Non-profit}

Earlier, in this study, it was assumed that there were two types of MFIs; not-forprofit and for-profit which provide financial return to their investors. Later, it is found that there are some institutions which basically attempt to earn profits but, only to cover the cost and enhance their operations further. Many times, they return only the loan amount to their investors without any interest. So, the issue of profitability of MFIs is also linked with their financial self-sustainability. One respondent argued that being forprofit or not-for-profit is not a main issue. She argues,

"Earlier profit was important for the sustainability of the MFI rather than for making the micro finance market lucrative to attract more investment."

According to her, important issue is the change happened in the basic objective behind earning the profit, in the last 10 years. Historically, MFIs were largely funded through donations/grants and government subsidies. In recent years, new sources of funds have emerged that are often described as having a focus on profitability (Ghosh \& Tassel, 2011). This issue raises the three important questions to answer in order to understand the reason behind such development; Do MFI really need external equity and/or debt funds? , Are donations, grants, and other subsidies not enough for the growing need of MFIs? and, What about getting funds within the operations, like accepting deposits from client? 
On asking these questions to the respondents, it was found that MFIs are in dire need of funds to explore new areas and start new services. It is found that fund raising exercise has become extremely tough for the not-for-profit MFIs after the recent financial crisis. The situation further deteriorated after the recent incidents of scam happened in microfinance sector of Bangladesh and India.

Many respondents also blamed regulation which is, according to them, time consuming, unsuitable and, costly affair. One respondent argued that donations are only good in the short run and when the scope of the microfinance is limited to a specific area. He claimed that external capital is must for the growth of the operation of MFIs and this is needed for the welfare of the poor. However, he mentioned that it was important to find out the right type of investors whose profit objectives match with the very nature of microfinance. According to him there is a need of 'patient' domestic capital which is still missing even in emerging economies, like India.

On the issue of providing saving services to clients, it is found that providing deposit services to clients is not an easy task for most of the MFIs due to many reasons. Almost all the respondents mentioned that the current regulation in many countries does not allow MFIs to accept deposits from clients. For example, in India and in some countries of Africa, MFIs have to register themselves as a business entity. This compels many not-for profit MFIs to get registered themselves as profit making entity or to restrict their financial operation to lending only. One not-for-profit MFI mentioned that to comply with the regulation in Africa, it had to get itself registered there as a commercial bank in order to accept deposits from clients. But, it reinvests all the profits for the welfare of poor people to remain attached with its mission.

Another very important issue raised by some respondents is of trust. They argued that from clients' perspectives taking loans and giving their hard earned savings are two very different issues. For the latter, an MFI has to devote a fairly long period in a particular area to become trustworthy. Some respondents mentioned that their savingsled programmes are growing very slowly due to low savings rate at most of the places where such programs are being implemented. The programme manager of one MFI states,

“...for example, in Burundi, people are generally saving equivalent of 5 pence at every meeting."

All the respondents agreed with the fact that strict regulation is needed for the safety of the clients' savings. Their main disagreement is with the way governments of different countries are handling the microfinance sector. They argued that often the same banking rules are applied on MFIs which favour only big players. The major problem for such MFIs is of following the capital adequacy norms, which are unfavourable to small 
MFIs. In this regard, one respondent, having wide experience of working in joint projects of UNDP with local banks and communities of Pakistan and Vietnam, argued that MFIs should try to collaborate with banks in place of providing savings services themselves. This sounds quite useful for MFIs, however, it is not always possible for small MFIs to collaborate with big formal financial institutions.

Some of the respondents highlighted that in some countries, the regulators have no clear understanding about how to deal with not-for-profit MFIs. Many times microfinance is even treated as payday loans. The CEO of one leading MFI even blamed the World Bank for not giving the real understanding of microfinance to African countries.

All these points clearly indicate that MFIs cannot increase their outreach only on the basis on savings made by clients. And, after the financial crisis, getting enough donations has become extremely difficult. Lack of funds from donations can create a threat to the very existence of not-for-profit MFIs. The average loan size provided by such NGOs are generally quite smaller than that of commercial microfinance bank (Cull et. al, 2009). Managing so many small size loans increases the operating cost of these organisations. This compels many MFIs to look towards financial markets.

\subsection{High rate of interest on microloans}

Generally, the rate of interest on microloans is higher than that of commercial banks. Muhammad Yunus argues that if the microcredit interest rate is more than 15\% above the cost of funds, then it is too high and within the loan shark zone (Yunus, 2009). But, many MFIs are found charging very high rate of interest (Kate \& Rouen, 2004). Banco Compartamos in Mexico was criticised for charging interest rates that exceed $100 \%$ per year on their loans to the poor (Karnani, 2009). In the Indian state of Andhra Pradesh, MFIs were turned out worse than the local moneylenders by charging very high rate of interest (Sharma, 2006). In the current study, issue of high interest rates, charged on loans, is raised with the respondents with an objective to find their opinion on this highly important issue.

All the respondents accepted that the rate of interest charged by MFIs on their microloans is higher than the interest rates charged by formal financial institutions. However, according to them, it's mainly because microfinance operations are very expensive. They argued that reaching to the poor clients in the remote village, far from the main city, is very expensive. Often, even the basic infrastructure is absent in these places. The loan officers have to travel a long distance. Also, in some areas, especially in Africa, rural population is widely scattered, making the operations more expensive. The MFIs deal with those clients who are financially weak and have no physical collateral. 
12 | MUDRA: Journal of Finance and Accounting, Volume 2, Issue 2

Many times MFIs have no idea about the credit worthiness of a particular client. Therefore, giving small loans to many clients not only increase the processing cost, but also the risk of loan defaults.

The not-for profit MFIs specifically mentioned that they operate lot of nonfinancial services which are very crucial for the sustainable development of the poor clients. Also, poverty is not just economic problem therefore, only financial help cannot solve this problem. It is important to train the client the basic skills, teach them about how to maintain financial records, and also make them aware about other important health and social issues. These all services are provided to them free of cost. This further put pressure on such MFIs to generate enough funds to run such activities. For them, after donations, only interest on loan generates funds. Taking deposits from clients is neither viable for all MFIs nor very helpful in the short run. In Figures 2 and 3, fund movements for not-for profit and for profit MFIs is shown, respectively. Funds generated from savings is not shown as most of the MFIs, interviewed, either not providing saving services or its share in total funds is negligible which gets counterbalanced from interest paid on such deposits.

Figure 2: Movement of Funds for Not-for-profit MFIs
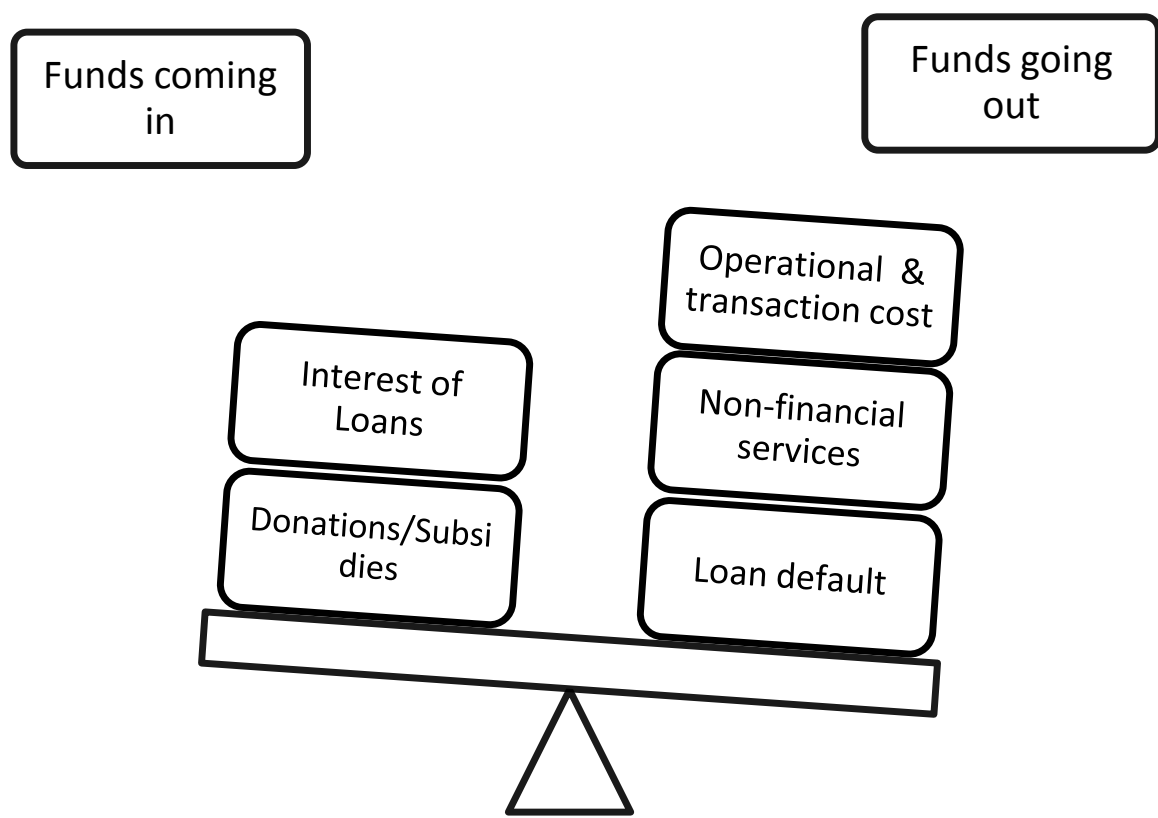

Note: Diagram is created on the basis on the information provided by the respondents interviewed in the study. 
Figure 3: Movement of funds in case of For-profit MFIs

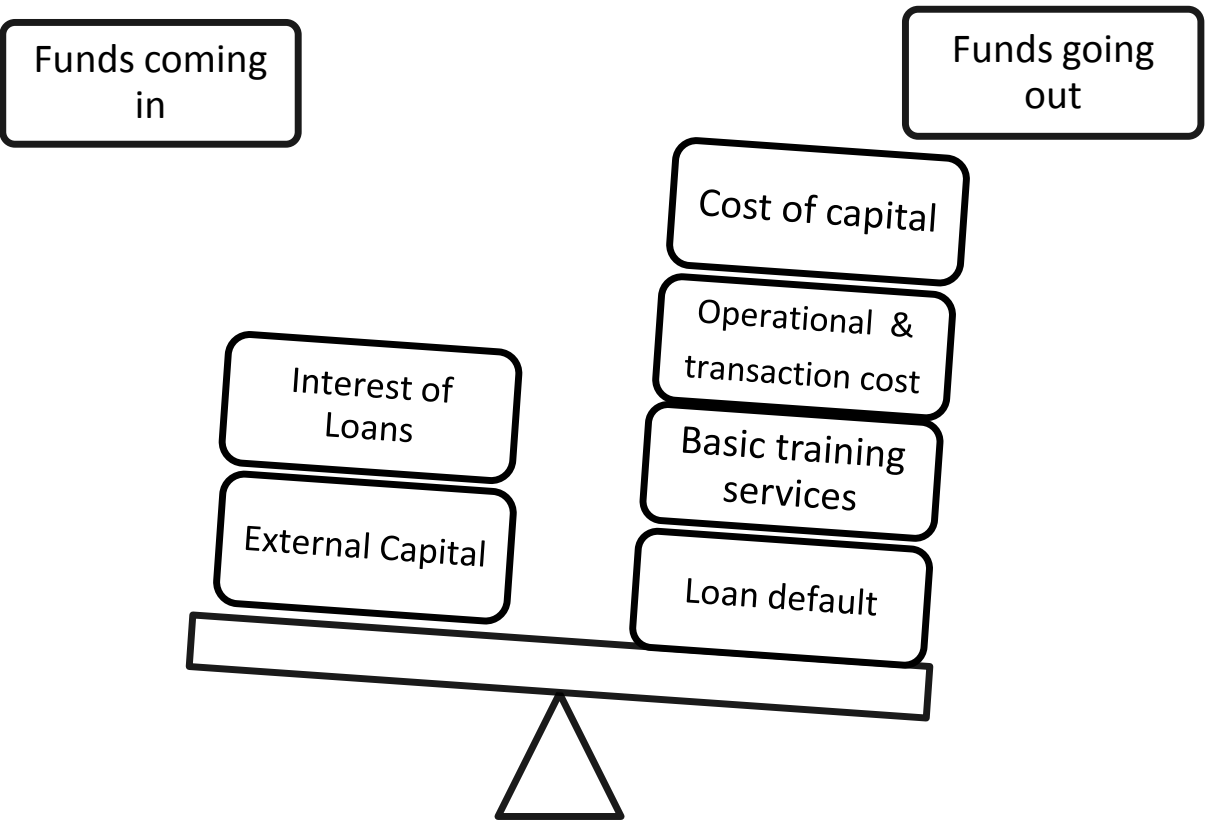

Note: Diagram is created on the basis on the information provided by the respondents interviewed in the study.

There is some relief for those MFIs, which are using external capital and, therefore, less dependent on grants. They are also found less involved in providing nonfinancial services (most of the time, just limited to financial literacy and business skills). They just have to maintain their operations in such a way which help the client to earn well and payback the loan with interest on time. But, for them, it is crucial to earn enough profit to give handsome return to their external investors to remain attractive for more investment.

However, many respondents agreed that with the view that there are fair chances that the balance between the financial and social performance of such MFIs turn into a trade-off. It is not always possible to earn high rate of interest without harming poor clients. There can be a locality where people are extremely poor and living far from the nearest town without access to basic infrastructure. And, in such situations, there are fair chances that such MFIs either ignore such markets or prove harmful for the particular region. If the poor clients cannot earn a greater return on their investment than the interest rate they have to pay, microcredit will prove harmful for them. Such situation, 
14 | MUDRA: Journal of Finance and Accounting, Volume 2, Issue 2

according to them, needs specifically designed financial products accompanied with many non-financial services including awareness programme on health, education, hygiene and, sanitation. In such settings, microfinance cannot survive without subsidies, at least in the short run.

\subsection{Conclusion}

The current study mainly aims to find how the issue of profitability influence the main objective of MFIs; eradicating poverty. In the light of the collective responses of the respondents, the study found that believing that MFIs can alone eliminate poverty is a myth. It questions the United Nations over hyped claim on the role of microfinance in poverty eradication. This claim rests on the assumption that everybody has capacity for entrepreneurship ${ }^{7}$. Any such belief by the policymakers, and so limiting their own role to just providing financial help to those MFIs, will make further delay in eradicating poverty.

The study also finds that microfinance cannot be treated only as a substitute of the traditional financial services. Such treatment will not only hide the uniqueness of the sector, but also ignore many important non-financial services provided by it to the poor clients. The true beauty of microfinance does not lie in just holding the clients, but in pushing them up to the next level of income, where they can enjoy wide range of financial products and services of the formal financial institutions. However, this distinct feature of microfinance makes the operations of the MFIs complicated. They have to reach to the poor clients living in the remote areas of the country, often illiterate and extremely vulnerable to external shocks. Here, directly jumping to financial services will not prove beneficial for both the parties.

Therefore, financial sustainability of microfinance seems to remain unachievable for most of the MFIs. This supports the finding of Rutherford (2000) and Morduch (2000). And, more focus on self-sustainability can make MFI unable to reach those who need the financial help more. This is in line with the findings of Van Pischhe (1996) that there exists a trade-off between financial self-sufficiency and depth of outreach.

The study also finds that there are fair chances of having trade-off between financial performance and social performance for those MFIs which borrow from financial markets. For them, the real challenge is to find that kind of investors who are not just driven by high returns on their investments, and their expectation of return is according to the very nature of the business of microfinance. Here it is more important to restrain from 'doing harm' than to 'doing good'. 


\section{Appendix: List of MFIs and Consultants of microfinance sector interviewed}

\begin{tabular}{|c|c|c|c|c|c|}
\hline & $\begin{array}{l}\text { Type of } \\
\text { Institution }\end{array}$ & $\begin{array}{l}\text { Area of } \\
\text { Operation }\end{array}$ & $\begin{array}{l}\text { Job Profile of } \\
\text { Interviewee }\end{array}$ & $\begin{array}{l}\text { Length of } \\
\text { Interview }\end{array}$ & Salient features \\
\hline 1 & Agora & $\begin{array}{l}\text { Cambodia, } \\
\text { India \& } \\
\text { Zambia }\end{array}$ & $\begin{array}{l}\text { Managing } \\
\text { Partner }\end{array}$ & 69 mins & $\begin{array}{l}\text { Use external source of capital; } \\
80 \% \text { clients are women }\end{array}$ \\
\hline 2 & Kubaru & & $\mathrm{CEO}$ & 50 mins & Peer-to-peer lending platform \\
\hline 3 & Opportunity & $\begin{array}{l}12 \text { countries } \\
\text { of AfricaIndia }\end{array}$ & Project Manager & 54 mins & $\begin{array}{l}\text { Over } 80 \% \text { clients are women; } \\
\text { Uses latest technology, having } \\
\text { satellite kiosk; more than } 400 \\
\text { training \& development } \\
\text { modules. }\end{array}$ \\
\hline 4 & Five talents & $\begin{array}{l}\text { India \& } \\
\text { different } \\
\text { countries of } \\
\text { Africa } \\
\end{array}$ & $\begin{array}{l}\text { Programme } \\
\text { Manager }\end{array}$ & 37 mins & Special focus on women \\
\hline 5 & $\begin{array}{l}\text { Microloans } \\
\text { Foundations } \\
\end{array}$ & $\begin{array}{l}\text { Malawi, } \\
\text { Zambia }\end{array}$ & $\mathrm{CEO}$ & 53 mins & Only women as clients \\
\hline 6 & FINCA & $\begin{array}{l}21 \text { countries } \\
\text { all over the } \\
\text { world }\end{array}$ & $\begin{array}{l}\text { Project Manager, } \\
\text { UK }\end{array}$ & 35 mins & $\begin{array}{l}\text { Initiated Village Banking } \\
\text { Campaign; gets funds from } \\
\text { variety of sources, including } \\
\text { financial markets. }\end{array}$ \\
\hline 7 & $\begin{array}{l}\text { Jenny } \\
\text { Hoffmann }\end{array}$ & & $\begin{array}{l}\text { Consultant } \\
\text { (Ex)CEO of MFI } \\
\text { Bank }\end{array}$ & 45 mins & $\begin{array}{l}\text { Worked with Profit making } \\
\text { institution; } \\
\text { Expertise in use of technology } \\
\text { in financial services }\end{array}$ \\
\hline 8 & P. E. Schoen & & Consultant & 78 mins & $\begin{array}{l}\text { Expertise in project } \\
\text { monitoring \& evaluation } \\
\text { service. Worked with DFID, } \\
\text { UNDP, etc. }\end{array}$ \\
\hline 9 & A. A. Tosoye & & $\begin{array}{l}\text { Executive } \\
\text { Director, The } \\
\text { Microfinance } \\
\text { Association, UK }\end{array}$ & 42 mins & \\
\hline 10 & K. D. Khan & & Consultant & 54 mins & $\begin{array}{l}\text { Worked with different } \\
\text { International organisation }\end{array}$ \\
\hline 11 & Sam & & $\begin{array}{l}\text { DFID and Citi } \\
\text { Development } \\
\text { fellow, } \\
\text { Consultant } \\
\end{array}$ & 52 mins & $\begin{array}{l}\text { Co-founder, Social } \\
\text { Performance Advisory }\end{array}$ \\
\hline 12 & $\begin{array}{l}\text { Katherine } \\
\text { Hughes } \\
\text { (CARE } \\
\text { International) }\end{array}$ & $\begin{array}{l}74 \text { poor and } \\
\text { developing } \\
\text { countries }\end{array}$ & $\begin{array}{l}\text { Financial } \\
\text { Inclusion } \\
\text { Programmes } \\
\text { Officer }\end{array}$ & 17 mins & $\begin{array}{l}\text { She is responsible for the } \\
\text { monitoring and evaluation of } \\
\text { micor-finance project s.She } \\
\text { has worked in Vietnam, } \\
\text { Rwanda etc. }\end{array}$ \\
\hline 13 & Inuka & $\begin{array}{l}\text { Different } \\
\text { countries of } \\
\text { Africa }\end{array}$ & $\mathrm{CEO}$ & 39 mins & $\begin{array}{l}\text { Only women as clients; } \\
\text { Peer-to-per lending platform }\end{array}$ \\
\hline
\end{tabular}


16 | MUDRA: Journal of Finance and Accounting, Volume 2, Issue 2

\section{Endnotes}

1. See Barr (2005); Yunus (2006 \& 2008); Vanroose \& Espallier (2013).

2. See Robinson (2001); Prahalad (2004); Collier (2007); Smith \& Thruman (2007); Gates (2008); Roy (2010).

3. See Barr (2005); Rena et, al. (2006); Bohara \& Johari (2008); Knight \& Farhad (2008); Shastri (2009).

4. See Matovu (2006); Brownstein et, al. (2007); Imai et, al. (2010); Johnson (2012).

5. See Islam (2007); Karnani (2009); Chang, (2010).

6. Such as BRAC's Targeting the ultra-poor programme and Kudumbashree in Kerala (Hulme \& Arun, 2011).

7. From report of the Secretary-General 'Role of microfinance in the eradication of Poverty' available at http://www.gdrc.org/icm/un-report.html

\section{References}

Besley, T. \& Coate, S. (1995). Group lending, repayment incentives and social collateral. Journal of Development Economics, 46, 1-18.

Brownstein, L., Fleck, P., Shetty, R., Sorensen, J., \& Vadgama, V. (2007). Pathways out of Poverty, Microfinance to Empower Sub-Saharan Africa. Discussion paper series, University of Mennesota, 1-57.

Cheston, S., \& Reed, L. (1999). Measuring transformation: Assessing and improving the impact of microcredit. Journal of Microfinance, 1(1): 20-43.

Dunn, Elizabeth. (2002). It Pays To Know the Customer: Addressing the Information Needs of Client-Centered MFIs. Journal of International Development 14: 325-334.

Dunn, K. (2005). Interviewing. In I. Hay (ed) Qualitative Research Methods in Human Geography (2nd edn., pp 79-105). Melbourne: Oxford University Press.

Gates, Bill. (2008). World Economic Forum - Creative Capitalism. Retrieved from http://www.gatesfoundation.org/media-center/speeches/2008/01/bill-gates-2008-worldeconomic-forum

George, A. (2005). India Untouched: The Forgotten Face of Rural Poverty. Cranston, Rhode Island, U.S.A.: Writers' Collective. 
Ghosh, S. \& E. Van Tassel. (2011) Microfinance and competition for external funds, Economics Letters, 112, 168-170.

Gillham, B. 2000. Developing a Questionnaire, London, Continuum International Publishing Group.

Gurses, D. (2009). 'Micro-finance and Poverty Reduction in Turkey'. Perspectives on Global Development and Technology, 90-110.

Imai, K S, Arun, T. \& Annim, S. K. (2010). Microfinance and household poverty reduction: New evidence from India. World Development, 38(12): 1760-74.

Islam, Tazul. (2007). Microcredit and poverty alleviation. London. Ashgate Publishing Ltd.

Karnani, A. (2009). Undermining the Chances of Sustainable Development in India with Microfinance. In Milford Bateman (ed) Confronting Microfinance: Undermining Sustainable Development, Virginia: Kumarian Press.

Karnani, A. (2011). Microfinance needs Regulation. Stanford Social Innovation Review, 48-53.

Kate, Daniel Ten and Van Rouen. (2004). The Cycle of Debt - As Microcredit Institutions Grow, Some Question Their Effect on Poverty. The Cambodia Daily, Feb. 21- 22.

Khandker, S (2005). Microfinance and poverty: Evidence using panel data from Bangladesh. World Bank Economic Review, 19(2): 263-86.

Kono, H. and Takahashi, K. (2010) Microfinance revolution: its effects, innovations and challenges. The Developing Economies, 48, 15-73.

Morduch, J. (2000). The microfinance schism. World Development 28: 617-629.

Prahalad, C.K. (2004). The Fortune at the Bottom of the Pyramid: Eradicating Poverty Through Profit. Upper Saddle River, NJ: Wharton School Publishing. 
18 | MUDRA: Journal of Finance and Accounting, Volume 2, Issue 2

Robinson, M. (2001). The Microfinance Revolution: Sustainable Finance for the Poor. World Bank. Washington DC.

Roy, Ananya (2010). Poverty Capital: Microfinance and the Making of Development' Routledge.

Sen, A. K. (1999) Development as Freedom. Oxford: OUP.

Sharma, S (2006). Death by microcredit. The Times of India, 16 September.

Shirazi, N.S., \& Khan, A.U. (2009). Role of Pakistan Poverty Alleviation Fund's and Micro Credit in Poverty Alleviation (A case of Pakistan). Pakistan Economic and Social Review, 215 - 228.

Sinha, S. (2011). Initial Public Offerings: the field's salvation of downfall? MCRIL.

Subbarao, D.(2009). Financial inclusion: Challenges and Opportunities. RBI Monthly Bulletin, January.

Valentine, G. (2005). Tell me about using interviews as a research methodology. In R. Flowerdew and D. Martin (eds) Methods in Human Geography: A Guide for Students Doing a Research Project (2nd edn).

Van Manen, M. (1990). Researching Lived Experience. London, Ontario: State University of New York Press.

Van Pischke, J. (1996). Measuring the trade-off between outreach and sustainability of microenterprise lenders. Journal of International Development 8, 225-239.

World Bank. (2008). Finance for All. Washington,DC: World Bank.

Yunus, M. (2006). Nobel lecture. Oslo. Available online at: http://www.nobelprize.org/nobel_prizes/peace/laureates/2006/yunus-lecture.html

Yunus, M. (2008). Social Business is the Solution. Available online at: http://www.mediatheque.lindau-nobel.org/videos/31406/social-business-is-the-solution2008/laureate-yunus 
Yunus, Muhammad (2009). Lifting People Worldwide out of Poverty.

Knowledge@Wharton. Available online at:

http://knowledge. wharton.upenn.edu/article.cfm?articleid=2243. 